\title{
The global information society: Some reflections on labour and work
}

\author{
Libby Bishop \\ Institute for Research on Learning, 66 Willow Place, \\ Menlo Park, CA 94025 USA \\ Phone: + 1415 614-7974; Fax: +1415 614-7957 \\ Email: Libby_Bishop@irl.org
}

\begin{abstract}
The global information society is fundamentally changing many aspects of modern life. One of the areas undergoing the most dramatic change is employment. Important shifts are occurring in the effects of information technologies on production, newly emerging occupational structures, structural unemployment, and so on (Krueger, 1993). Technology changes how we labour. As important as these issues are, there is also a broader question, namely, the implications of this information society for work itself. Here, I am distinguishing labour from work: by labour I mean the conditions under which we act on and with the material world, whereas work means not just what we do to survive, but what we make and create in order to live as humans ${ }^{1}$. I am addressing the question: what does work mean as a social category: for society as a whole, as an entitlement to economic resources, for the self, and the constitution of identity? My claim is, the consequence of information technology is not merely that we are labouring differently, but rather, the meaning of work is changing. This paper addresses and reflects on some of the implications for labour and work of an information society.
\end{abstract}

\footnotetext{
I find Arendt's (1958) distinction between labour and work a useful one, although I am not following her definitions here. Her argument that the only realm for human relations is vita activa, I find too limiting. I would argue with Aronowitz and DiFazio (1994) and, drawing on Marx, that work too can be an authentic human activity. Implicit in Arendt's and others' devaluation of work is, I believe, a privileging of mind over body, or contemplation over action, with which I am not comfortable.
} 


\section{WHAT IS NEW ABOUT AN INFORMATION SOCIETY?}

Technological change is enabling a shift from a Fordist system of mass production of goods to a postmodern world based predominantly on services and knowledge work (Coriat, 1992; Piore and Sabel, 1984). The key characteristic of this transition is the move from 'fixedness' to flexibility. The ideal type of Fordist work was the assembly line. It was marked by the rigidity of high levels of fixed capital, inflexible labour markets and work rules, very narrow and specialized occupational categories, and significant rigidity in consumption, i.e., mass marketing of standardized goods. Flexible accumulation has challenged this model with downsizing and corporate divestitures creating smaller, allegedly more nimble businesses. On the labour front, firms are attempting to use high percentages of contingent workers (part-time and/or temporary) in order to reduce their wage costs. Production is more often team-based, with broader job categories, flatter organizations, and reduced bureaucratic hierarchy. Finally, marketing has dramatically changed from mass to niche, sometimes even to personalized products (e.g., my Internet-provided Wall Street Journal Interactive Edition provides only the stories my 'profile' knows I will like).

Within this complex of changes, probably the most important is the shift from making things to manipulating information or other symbols (Bridges, 1994; Zuboff, 1988). It has disrupted assumptions about time, space and work that had been in place since the Industrial Revolution (Harvey, 1990). The factory system came about, in part, because the existing technologies were best suited to synchronous work, i.e., people had to be working at the same time to coordinate their activities. (In addition to these technical requirements, issues of power and control also shaped these decisions (Marglin, 1974).) Workers had to be spatially collocated, i.e., in the same factory, in order to weave, smelt, etc. Much of the wrenching cultural transformation of the Industrial Revolution concerned making the shift from agrarian to industrial time and from countryside to factory (Thompson, 1966). No less wrenching is our current shift from industrial to Internet time, and from factory to virtual office.

\section{LABOUR, WORK AND CHANGING SPATIAL CONFIGURATIONS}

Information technology has greatly altered the spatial and temporal constraints on work. Although many of these technologies remain imperfect, hard to use, and no substitute for face-to-face interaction, some tools such as electronic mail, fax, intranets, etc., do allow much work that had to be collocated and synchronous to be done 'anywhere, anytime'. One of the most visible changes is the physical displacement of work. A 1995 survey by the International Facility Management Association shows that $83 \%$ of companies are using alternative office strategies, ranging from innovative layouts to hotelling (no dedicated offices, employees check into non-personal space) and telecommuting. Telecommuting, for example, is used by over one-third of U.S. businesses (with 100 or more employees), and over two 
million employees telecommute (Gemini Consulting, 1993). What do these new spatial arrangements say about how work is changing?

Before addressing this question directly, it is necessary to step back and look more generally at the complex and interactive effect between the physical environment of work (office, partitions, furniture) and its social relations. They mutually affect each other. The space can shape what kinds of work happens (widely dispersed private offices deter collaboration) and what work needs to get done shapes space (people who do not have space for visitors' chairs improvise with portable stools).

I have recently been engaged in a project studying office environments, collaboration and work practices. In this case, the initial focus was to explore the potential benefits of mobile furniture. The company was in the process of office renovation: from an existing open layout (no offices, low partitions) to a more enclosed, high partition environment. One information systems group decided they did not like the new design. Their primary objection was the height of the new partitions (about 72") that were too high to see over, even when standing up. The members of this group needed to communicate and collaborate extensively, and they feared the high partitions would block that.

As an alternative, a small group agreed to pilot yet a third configuration of furniture and office layout. This new furniture is highly mobile, literally all pieces are on wheels. Also, rather than partitions, there is a mesh scaffolding which offers semi-privacy, and storage devices hang from the scaffold.

The more flexible furniture made the relation between the work done and the environment 'visible' in new ways. Specifically, the mobility of the furniture allowed more detailed aspects of the work practices of the team to become visible. For example, there were a lot of finely-grained adjustments of teams and groups that took place. With the flexible furniture, these adjustments could be accommodated as the furniture could be adjusted to small-scale groupings and regroupings. Under the traditional facilities model, moves happen only when new buildings open, teams relocate, etc. These micro-level adjustments-that occur on a time-scale of hours, days or weeks, not months or years-had not 'appeared' or become visible in the previous, more rigid, physical environment.

This experiment in mobility speaks to issues of both labour and work. It demonstrates in what ways spatial flexibility is showing up in labour. Examples include the open office as embodying flatter organizations; team, not individual, based organizations; and project-based work that requires ongoing adjustments in team membership. While I am not suggesting these are insignificant, they do not address a broader insight about work. Just as the mobile furniture is making some previously invisible work practices visible, the effect of information technology more generally is to make some aspects of work, namely the changing relationship between employer and employee, more visible as well.

This process of making visible is revealing in physical forms, the rapidly changing nature of the employment relationship. What is being heralded as the virtual corporation takes on a different meaning when viewed in this light. Hotelling, telecommuting and telecentres are physical embodiments of work-at-adistance. But what has not received as much attention is that the weaker geographical and physical bonds to the organization are, in many respects, a metaphor for the weaker affective bond as well. Casey (1995) calls the effect a 
'decentered workplace'. Work-at-a-distance takes on the figurative, as well as the literal, sense of being distant from the centre of the organization. Just as workers no longer need to be central, similarly work may no longer need to be central for such workers.

If we look at the implications of information technology for work, not just labour, it appears to point to a weakening relationship. It appears that our bonds to the workplace, and hence to work, are weakening. This is being manifested in the business press as the 'new social contract,' 'the end of the job' and 'the new employment rules'. In general, what has changed is that the old contractemployment security in exchange for hard work and loyalty-is no longer in effect. More analytically, issues of commitment and loyalty are being addressed by academic researchers as well (Heckscher, 1995; Kunda, 1992). Information technologies and accompanying spatial reconfigurations are not so much causing this shift as they are creating affordances for the changes in the employment relation to become visible.

\section{LABOUR, WORK AND CHANGING TEMPORAL CONFIGURATIONS}

Unlike the Fordist emphasis on the uniformity of the 40-hour week, post-Fordist work models compress and stretch time in new ways. One television advertisement opens with an aerial view of an approaching car. The setting is stunning, something like the Badlands in the United States-glorious red rock hills, winding empty road, a solitary driver. Suddenly the driver stops, gets out of the car to stretch, pulls out a laptop, and sends a fax. Anytime, anywhere. However, the virtual technologies that promise freedom to work any time, ironically, enable us to work all the time. The work week is at an historically record high. The compressing and stretching of time makes the all-too-real work getting done disappear, and become invisible, as we fill our commuter journeys with phone calls and our 'leisure' with self-service work.

After many years of 'time-saving' technologies, work hours are up, not down. The manufacturing work week is still near post-war highs of about 48 hours. The average employed American is working 163 hours-nearly a month-longer per year in 1987, compared to 1969 (Schor, 1992). There are many confirming minor indicators: only $2-4 \%$ of those eligible took time off under the United States Family and Medical Leave Act and $90 \%$ of lunch breaks are 30 minutes or less. Also, telecommuting hours take place more often in addition to time at the office, not in place of it (Perin, 1991). Rather than saving time, the macro-level data on working hours present a different picture, summarized in The Overworked American (Schor, 1992), of people working more for stagnant real wages.

Once again, the labour/work distinction is a useful window into this issue. As with space, the implications of technologies that support work 'anytime' have schizophrenic effects. They afford much greater flexibility and latitude, often relished by those with competing obligations of work and family.

Yet, the reality of flexibility is that it often becomes not working later instead of now, but later and now. In this environment of job-churning, downsizing, etc., the indirect pressures to work long hours are nearly irresistible. In $1995,44 \%$ of 
surveyed workers report workload is excessive, up from $41 \%$ in 1991 and $37 \%$ in 1988. More specifically, in my own research projects, I have encountered examples of how employees were offered computer-based training in lieu of the 'obligation' to attend classes. The online class was specifically developed to minimize time away from work. But one participant reported spending 10-12 hour regular work days, then having to do his training in the evenings. He was thus unable to lead a normal life with his family. He said he was seriously reconsidering the advantages of a 1-week off-site class where his co-workers would cover for him, and he was less subject to burnout.

Even when the problem is not more total work hours, there are costs as well as benefits to the flexibility of splicing time between work and life. One story captures the feel of this tension:

'I work at [my child's] volleyball practice. I took my laptop. I think I was working on a dealer letter about the status of some of our products. I had time in the car with my child on the way to practice and on the way back. As for volleyball practice, I didn't actually have time to watch. It was something about me being there. So I sat in the gym stands and worked on the letter.' (Fishman, 1996)

What is lost? There is an assumption here that we can parse work into everfiner increments, that all these work/life time units are, somehow, interchangeable.

However, the implications for work, in addition to these effects of 'timeshifting' on labour, are, in the longer view, perhaps even more significant. We miss the broader implications for the meaning of work if we address only the literal level. What are people trying to signify with their overwork? Much time at work is now largely symbolic, and in fact, attempting to compensate for the decline in physical presence. Workers are trying to show loyalty, commitment and so on, through their sunrise meetings and all-night efforts, precisely because their more formal and contractual ties to the organization are fraying (Casey, 1995; Perin, 1991).

As we saw with space, the malleability of time is uncovering and making visible changes in work, specifically in the structure of employment relations. Time-based competition is being extended from manufacturing to managing human resources. Just like industrial plants are supposed to retool overnight for new model production, now humans are also supposed to 'retool', creating several careers in a lifetime. Guaranteed employment is being replaced by 'employability', with the additional requirement that employees willingly engage in continuous learning. And many times, we see one dimension, in this case speed, pushed to ridiculous extremes:

'It should be perfectly clear to all of us that speed is a key source of competitive advantage ... Of course, a company can't be fast if its people are slow. It can't rapidly adjust to change if employees resist ... Our mindset should be to think of ourselves as accelerators for the organization. Our job is to bring speed to everything we touch' (Pritchett, 1996).

Many aspects of this new employment relation are attractive: the flexibility of trying many careers, the opportunities for innovation relatively free of traditional hierarchical control, and the occasion to engage in new learning. And yet, despite the long hours spent at work, work no longer provides the same central framework for self-definition and identity. Casey (1995) argues that a fundamental shift has 
occurred at work, exemplified by continuously reconstituted project teams. As workers become more cross-trained, more flexible, and experienced in aspects of what were formerly multiple careers or jobs, these workers can no longer look to any particular job, career, or occupation as central to who they are. Ironically, corporations have created precisely the autonomous, non-specialized, interchangeable worker-widget they claim to need.

\section{CONCLUSION}

The question, which remains as yet unanswered, is whether or not corporations can operate effectively with this 'no commitment, no loyalty' model of employment that is emerging. I will hazard a prediction that such a model of work, based almost exclusively on contractual instrumental relations, will founder for want of the affective and social community aspects of the workplace that make it human as well as productive.

\section{REFERENCES}

Arendt, Hannah. The Human Condition. Chicago: University of Chicago Press, 1958.

Aronowitz, Stanley and William DiFazio. The Jobless Future. Minneapolis: University of Minn. Press, 1994.

Bridges, William. Job Shift: How to Prosper in a Workplace without Jobs. Reading, MA: AddisonWesley Publishing Company, 1994.

Casey, Catherine. Work, Self and Society: After Industrialism. London: Routledge, 1995.

Coriat, Benjamin, The revitalization of mass production in the computer age, in Michael Storper and Allen Scott, eds., Pathways to industrialization and regional development, pp. 137-156. London: Routledge, 1992.

Fishman, Charles, We've seen the future of work, Fast Company. Aug-Sept, 1996, pp. 53-62.

Gemini Consulting, Telecommuting Research and Implications for Silicon Valley, October 1993.

Harvey, David. The Condition of Postmodernity. Cambridge, MA: Blackwell, 1990.

Heckscher, Charles. White-Collar Blues. New York: Basic Books, 1995.

Krueger, Alan, How computers have changed the wage structure, Quarterly Journal of Economics, Feb. 1993, pp. 33.

Kunda, Gideon. Engineering Culture: Control and commitment in a high-tech corporation. Philadelphia: Temple University Press, 1992.

Marglin, Stephen, What do bosses do?, Review of Radical Political Economy, 6:2, 1974, pp. 60-112.

Perin, Connie, The moral fabric of the office, in S. Bacharach, S. Barley, and P. Tolbert, eds., Research in the Sociology of Organizations. Greenwich, CT: Sage, 1991.

Pritchett, Price, Mindshift: The employee handbook for understanding the changing world of work, Dallas, TX: Pritchett and Assoc., Inc., 1996.

Piore, Michael and Charles Sabel. The Second Industrial Divide. New York: Basic Books, 1984.

Schor, Juliet. The Overworked American. New York: Basic Books, 1992.

Thompson, E.P., The Making of the English Working Class. New York: Vintage Books, 1966.

Zuboff, Shoshana. In the Age of the Smart Machine. New York: Basic Books, 1988. 